\title{
Practice and Innovation in 'Science of Tourist Guide' Curriculum Reform-Summarizing classroom teaching reform experience and implementing spirit of the 19th National Congress of the Communist Party of China from practice
}

\author{
Xiao Zhao \\ College of Finance and Economics, Qinghai University, Xining, China
}

\begin{abstract}
Keywords: Spirit of the 19th National Congress of the Communist Party of China, Science of Tourist Guide, classroom teaching reform, experience and innovation.
\end{abstract}

\begin{abstract}
Two major judgments were made clear in the 19th National Congress of the Communist Party of China 'socialism with Chinese characteristics enters into the new era' and 'main contradiction change of society in China'. Social main contradictions in China has been converted into 'the contradiction between 'people's increasing demand on high-quality life and unbalanced and insufficient development'. Satisfaction of current people's demand on tourism is just one of contents and forms of 'high-quality life'. Tourism professionals seem very important in the process of satisfying tourism demand- 'high-quality life'. We should constantly drive comprehensive reform of tourism professional education teaching, actively explore and study approaches for classroom teaching reform innovation development, and make efforts to cultivate innovative spirit and practice ability of students majoring in tourism. In the paper, the spirit of the 19th National Congress of the Communist Party of China is regarded as the guidance, 'Science of Tourist Guide' curriculum reform is regarded as the focus, experience in classroom teaching and examination comprehensive reform is summarized, demands of Qinghai tourism on guide talents are combined for striving to explore approaches of 'Science of Tourist Guide' classroom teaching reform innovative development, thereby cultivating tourism talents with higher innovation spirit and practice ability.
\end{abstract}

\section{Introduction of curriculum, objectives and positioning in professional training plan}

'Science of Tourist Guide' is a professional basic course of tourism management major, and it is compulsory and composed of 48 class hours and 3 credits. Its objects include undergraduate students majoring in tourism management. The curriculum has the following objectives in tourism management professional training plan: to foster applied and complex talents with 'innovation awareness, entrepreneurial spirit and practice ability', who can 'engage in operation, management, services and similar work' of tourism enterprises. Students' professional accomplishment is improved through overall learning of the curriculum, therefore students can master general theory and working methods of Science of Tourist Guide, thereby better serving subsequent learning of the curriculum. Students can achieve corresponding ability to work.

'Science of Tourist Guide' is in the basic position in the whole professional curriculum system. It serves as a link between past and future for students to better study following curriculum. Students are cultivated into 'practical' applied talents through accepting basic training the aspect of tourism and mastering the basic ability of analyzing and solving problems. In addition, students' innovation awareness and entrepreneurial ability are cultivated more importantly through theory and practice learning, and preliminary theory study is provided for establishing travel agencies and related tourism consulting service companies especially through accumulating a lot of team leading and related experience. 


\section{Problem in teaching before reform and student analysis}

\subsection{Classroom teaching mode is too traditional, which can not adapt to guide development demand in new era}

First of all, existing curriculum teaching syllabus is comprehensive, but the existing teaching method (theoretical teaching and experiment) cannot adapt to the requirements of the curriculum.

Secondly, the existing teaching syllabus does not involve the item of specific measurable result, thereby comprehensive and objective assessment of learning effect cannot be obtained in the curriculum at the end of the teaching task;

Thirdly, teaching arrangement in existing teaching syllabus is relatively fixed. However, it may be changed in actual teaching process, such as regional teaching of municipal, provincial and national leader in the field of related discipline, guide competition at all levels, national guide teacher library selection activity, provincial and national excellent guide teaching activities and similar activities, which is more beneficial for students to better grasp the curriculum and current research topics of the most attention, etc. However, relatively fixed traditional teaching method does not support participation in the above activities, thereby leading to disconnection between learning of the curriculum and social market demands, which cannot adapt to guide development needs in the new era.

Fourthly, the teaching syllabus of the curriculum is not related to 'discussion-based teaching model' and 'cooperative teaching' currently, individual chapters are suitable for 'flipping classroom' teaching model, which cannot be implemented. Existing teaching method mode belongs to 'theoretical instruction + case discussion', case discussion only refers to discussion similar to case nature, the discussion topic, time, content and form are relatively fixed. There is till a greater gap from harmonious, vivid, pleasant and efficient topic construction.

\subsection{Traditional education evaluation form and examination method cannot reflect the learning effect of students comprehensively and objectively.}

Firstly, existing traditional exam of the curriculum does not focus on 'process' at present, which more focuses on 'result'.

Secondly, current assessment form is single, and the proportion of final exam results is more than $60 \%$, and the evaluation mode belongs to answer closed-book test.

Thirdly, since final exam result accounts for a large proportion in the evaluation mode, students are prone to the phenomenon of relaxing process learning due to pursuit of high score. Therefore, it is necessary to boldly innovate and strengthen process assessment in the curriculum examination reform.

Two above aspects are summarized, curriculum 'Science of Tourist Guide' is confused in the aspects of classroom teaching and examination evaluation of the curriculum 'Science of Tourist Guide' (see figure 1).

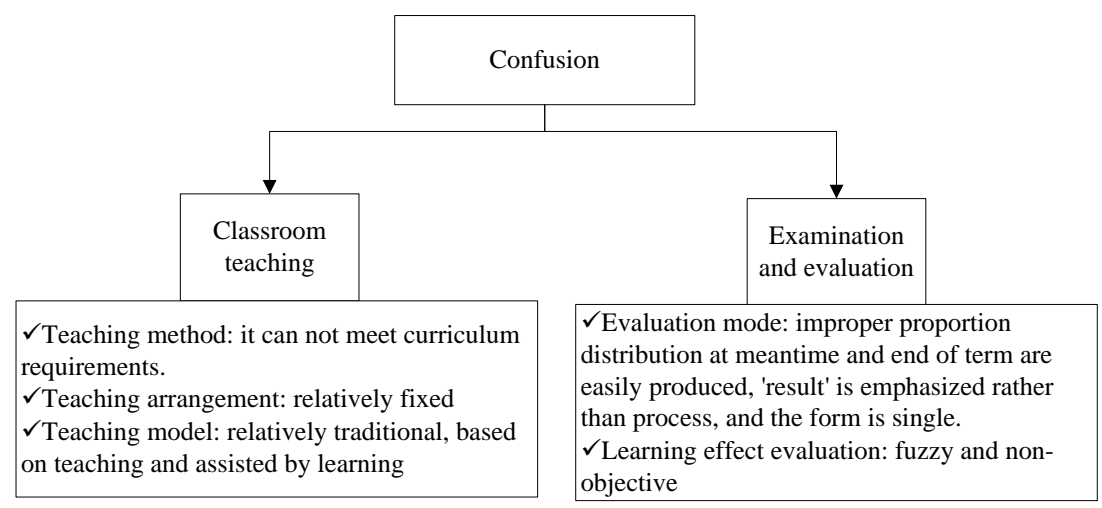

Figure 1. Graphical representation of existing problems in curriculum 'Science of Tourist Guide'

\subsection{Student analysis}

The curriculum teaching object is undergraduate students of Qinghai University majoring in tourism management. Student sources of the class show that mainlander students account for $30 \%$, the remaining students are born in the province, preppies account for about $20 \%$, minority students account for larger proportion since the university is located in ethnic minority area, which can 
generally reach $30 \%$. Girls account for higher proportion in the teaching class, mainlander students are equal to preppies in the province, the minority students in the province are more, the phenomenon reflects that student levels are different in the class, and there is prominent difference in acceptance degree. Therefore, students and teachers are not satisfied due to traditional teaching method.

\section{Guiding ideas and objectives of course reform}

'Tourism Method', 'Guidelines of National Tourism Administration on Promoting Guide Industry Organization Construction', tourism brand upgrading objectives of 'Damei Qinghai' about guide industry construction, innovative entrepreneurial talent training of Qinghai University, Tourism Management of School of Finance and Economics, other key professional construction as well as tourism management major training objective of tourism public management department, etc. are regarded as the guiding ideology of the curriculum reform.

Harmonious, vivid and pleasant classroom teaching environment is created; the teaching strategy based on student development is highlighted, and it focuses on learning, which is assisted by teaching and participated by students. Teaching design is diversified, students' desire of actively exploring knowledge is stimulated through project driving, cooperative learning and other modes, students are guided to change from passive learning into active learning, thereby obtaining the best education quality and efficiency. Teaching process management is refined, originally education evaluation mode of singly focusing on results and curriculum evaluation mode are changed, learning process quality control is emphasized, thereby actually improving the teaching quality.

\section{Curriculum reform practice and innovation}

\subsection{Teaching method tentative reform}

Traditional teaching mode is changed to teaching mode of 'teaching + scene simulation+ practice' during 'Science of Tourist Guide' classroom teaching reform process, wherein theoretical instruction is carried out through 'diversification of teaching subject+ multidimensional teaching method', situational simulation and practical teaching are conducted with the help of Qinghai University campus and Xining downtown landscape.

Firstly, teaching refers that multi-dimensional teaching mode is combined on the basis of previous teachers as single teaching subject, therefore the teaching subject is diversified, off-campus guide field experts, excellent tour guides and players of tour guide contests at all levels, graduation brothers or sisters engaged in the field are invited to theoretical instruction of the curriculum in addition to teachers in the curriculum group. Namely, the teaching subject is enriched through the mode of 'famous guide executive upper classman in classroom'. 'Flipping classroom' teaching method is adopted for contents of individual chapters of the curriculum. Students are allowed for teaching, students answer mutually, teachers appraise, and teachers answer the problems that can not be answered by the teaching group. In addition, teaching modes are multi-dimensional. Curriculum class network learning group is established to record important contents of the curriculum into video in addition to the traditional classroom teaching, the video is provided to students for studying anytime and anywhere. In addition, bus and scenic spots are utilized, and the video is used as a mobile classroom for teaching during the process of investigation in downtown area.

Secondly, scene mode refers that tour guide scenario simulation training is carried out with the aid of Xining scenic spots, text creation and audio recording of 'Micro-Qinghai' commentary are finally finished through a lot of investment of energy before, during and after class. The achievements are applied to classroom teaching and student national guide qualification certificate examination, and excellent effect is achieved during practical tour process.

Thirdly, campus practice: guide commentary of Qinghai University is completed tentatively and roughly with the aid of campus and school history data of Qinghai University, new students and parents are toured in the campus for two consecutive years during new student reception. 


\subsection{Exploratory reform of teaching arrangement}

The exploratory reform of teaching arrangement is closely related to teaching method reform. Different teaching arrangements are adopted for different teaching methods, such as student-based flipping classroom teaching method. Tasks can be arranged two weeks in advance. Task blocks are divided to different groups, which are further divided into specific persons. Various preparations before task completion are done according to different labor divisions. Different groups can question and review mutually during classroom teaching process. Finally, keys, difficulties and unsolved problems are summarized, and teachers are responsible for answering problems.

\subsection{Tentative reform of teaching model}

Real-time student group characteristics and individual differences are combined to establish an interest group in the learning process of the whole curriculum according to the characteristics of the curriculum content section. Each interest group dispatches tasks suitable for the group. The task completion time is determined according to curriculum study progress and task difficulty. After final tasks are completed, the task is reported and appraised, thereby encouraging people to make efforts continuously through the mode of reality inspiration (such as issuance of guide commentary edited by curriculum group or a paper about excellent scientific achievement in corresponding field or material incentive, etc.), and specific measures are shown in figure 2.

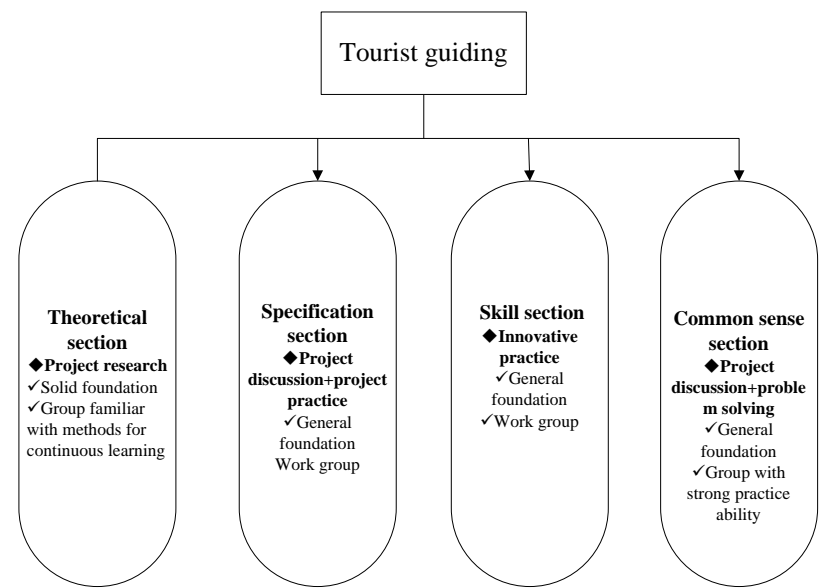

Figure 2. Graphical representation of 'Science of Tourist Guide' teaching model change

According to the above figure 3, teaching model reform is generally shown as follows: student situation and teaching resources are combined for designing in a targeted mode according to teaching contents of four sections on the basis of the best teaching effect as the principle. Firstly, 'theoretical teaching+project research' mode is mainly adopted in the theoretical section, wherein the group comprehending certain research method with solid basic knowledge in the class is responsible for completing the task; secondly, 'theoretical instruction+project research+project practice' mode is mainly adopted in the specification section, and the mode is targeted to groups with general basic knowledge and stronger practical ability, which work directly after graduation according to plans, thirdly, 'theoretical instruction+Innovative practice' mode will be adopted in the skill section, and the mode is targeted to groups with general basic knowledge, who dare to think and dare to do. Fourthly, 'theoretical instruction+ project discussion+problem solving' mode is adopted for common sense section, and it is targeted to student groups with general basic knowledge and strong practical ability.

\subsection{Examination reform and teaching effect evaluation}

\section{EVALUATION MODE REFORM}

Firstly, daily scores and final exam in the examination mode form the harmonious proportion. 5:5 proportion is adopted. Process is emphasized. Secondly, assessment form is enriched, 'written test + interview + project result' mode is adopted. Thirdly, the examination mode is diversified, 'audio + picture + test paper + project result report' form is adopted. Since the curriculum belongs to an examination course during final examinations, the examination modes of 'one piece of paper' and curriculum summary with mind mapping are adopted. Closed-book written test is adopted in the final 
examination. However, examinee only can take 'one piece of paper' with size of no more than A3. All knowledge points of the curriculum can be recorded in advance on the paper, while students should produce the mind map of the curriculum in the site through recalling and reproduction mode during final examination. The examination does not aim at 'examining' students, but testing the learning effect. The above-mentioned innovation-based evaluation mode lowers the examination difficulty of students and puts an end to students' cheating idea on the one hand, student 'examination' is changed into systematic mastering of curriculum contents by students more importantly on the other hand, and the mastery of students on the curriculum can be discovered more comprehensively through the mode of mind map recalling and reproduction.

The curriculum examination system reform follows the principle of objectively and fairly reflecting students' learning situation as a whole. It aims at embodying emphasis on process learning and emphasis on participation. Students can master theoretical knowledge through 48-hours learning. Meanwhile, they should learn to apply knowledge. Specific conditions are shown in table 1.

Table 1 Student curriculum academic record structural table

\begin{tabular}{|c|c|c|c|c|c|c|c|c|}
\hline \multirow{2}{*}{$\begin{array}{c}\text { Score } \\
\text { composition }\end{array}$} & \multicolumn{5}{|c|}{ Daily examination 50 points } & \multicolumn{2}{c|}{$\begin{array}{c}\text { Final examination } \\
50 \text { points }\end{array}$} & Total \\
\cline { 2 - 9 } & Attendance & $\begin{array}{c}\text { Operation } \\
\text { score }\end{array}$ & $\begin{array}{c}\text { Classroom } \\
\text { performance } \\
\text { score }\end{array}$ & $\begin{array}{c}\text { Investigation } \\
\text { report and } \\
\text { sharing }\end{array}$ & $\begin{array}{c}\text { Simulation } \\
\text { training }\end{array}$ & $\begin{array}{c}\text { Written } \\
\text { test }\end{array}$ & Interview & score \\
\hline Score & 5 & 10 & 5 & 15 & 15 & 30 & 20 & 100 \\
\hline
\end{tabular}

Note: daily score contains additional bonus items: praise score from tourists in tour practice (5 points are added in daily score if tourists give praise), completion of additional operation ( 5 scores are added), etc.

\section{LEARNING EFFECT EVALUATION}

Firstly, a reasonable concrete evaluation system is established for constructing evaluation index. The evaluation the index system is divided into two main sections: theory and practice. Secondly, students' learning effect is evaluated objectively, and 'evaluation according to talents' is created, high score is not the only standard, discussion process and result, research conclusion and subsequent project application, field guide, tourist evaluation and innovation results (commentaries in English and Chinese as well as entrepreneurship preparation), etc. are combined, and objective and rational learning effect evaluation is given to students.

\section{Acknowledgements}

This paper is supported by 2015 Qinghai University 'Science of Tourist Guide' classroom teaching and examination comprehensive reform project (KG-15-12) and 2016 Qinghai University School of Finance and Economics 'Science of Tourist Guide' classroom teaching and examination comprehensive reform supporting project.

\section{References}

[1] Xi Jinping. Construction of a moderately prosperous society in all respects with decisive victory and seizure of great victory of socialism with Chinese characteristics in the new era. http://news.xinhuanet.com/politics/19cpcnc/2017-10/18/c_1121822489.htm. 